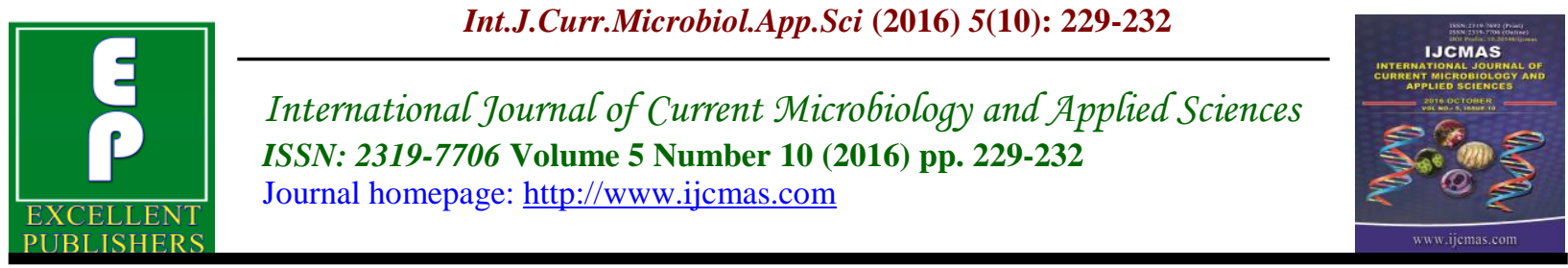

Original Research Article

http://dx.doi.org/10.20546/ijcmas.2016.510.024

\title{
Isolation and Speciation of Candida from Vaginitis Cases attending Gynaecology OPD in a Tertiary Care Hospital A.P. India
}

\author{
Ponugoti Muni Lakshmi* \\ Department of Microbiology, Narayana Medical College, Nellore, India \\ *Corresponding author
}

\begin{tabular}{|c|c|}
\hline & A B S T R A C T \\
\hline $\begin{array}{l}\text { Ke y w o r d s } \\
\text { Vulvo vaginal } \\
\text { candidiasis, } \\
\text { vaginitis, } \\
\text { Non albicans } \\
\text { candida, } \\
\text { Candida albicans. } \\
\end{array}$ & \multirow{3}{*}{$\begin{array}{l}\text { Vaginitis is one of the commonest causes for the gynecology consultation } \\
\text { among women of child bearing age.It is difficult to distinguish between Vulvo } \\
\text { vaginal Candidiasis (VVC), Trichomonas vaginalis and Bacterial Vaginitis } \\
\text { infection based on signs and symptoms only. The present study was undertaken } \\
\text { to isolate the various species of Candida causing VVC and to highlight the } \\
\text { importance of non-albicans Candida in VVC. This prospective study was done } \\
\text { over a period of six months from february } 2016 \text { to july2016 in Narayana } \\
\text { medical college, Nellore, A.P., India. A total } 150 \text { samples were collected from } \\
\text { patients clinically suspected and diagnosed as VVC,among these we isolated } \\
\text { candida in } 126 \text { samples. Among the } 126 \text { samples C.albicans isolated in } 40.48 \% \text {, } \\
59.52 \% \text { non albicans species. It indicates the importance of isolation of non } \\
\text { albicans species in VVC. }\end{array}$} \\
\hline$A$ & \\
\hline $\begin{array}{l}\text { Accepted: } \\
\text { 12 September } 2016 \\
\text { Available Online: } \\
10 \text { October } 2016\end{array}$ & \\
\hline
\end{tabular}

\section{Introduction}

Vulvovaginal candidiasis is caused by overgrowth of Candida yeast species in the vagina and is characterized by curd-like vaginal discharge, itching, and erythema (Achkar et al., 2010). It is difficult to distinguish between Vulvo vaginal Candidiasis (VVC), Bacterial Vaginitis and Trichomonas vaginalis infection based on signs and symptoms only leading to suboptimal care (Sobel, 1985, 1992). Vulvovaginal candidiasis has been associated with considerable direct and indirect economic costs (Foxman et al., 2000). The present study was conducted to determine the various species of Candida in causing VVC and to highlight the importance of non-albicans Candida in VVC. Various studies have shown that $75 \%$ of healthy adult women will suffer with at least one episode of Candida infection during life time and 5\%will have recurrent episodes (Hurley, 1981). Candida albicans is the common pathogen in $80-90 \%$ of cases but non albicans species are gaining importance as pathogens over the past few decades (Kent, 1991).

\section{Materials and Methods}

This prospective study done by collecting samples from 150 patients with Vulval 
pruritis, Dysuria, Curdy discharge attending gynaecology OPD, Narayana Medical College over a period of six months February 2016 to july 2016 . Two vaginal swabs were collected from the lateral walls of vagina by sterile cotton tipped swabs. One of them was used to prepare a direct smear and to perform gram staining. The other swab was inoculated on Slants of Sabourad's Dextrose agar with added gentamicin $(0.06 \mu \mathrm{g} / \mathrm{ml})$ and plates of Hichrome Candida differential agar (Himedia laboratories, Mumbai). The plates and slants were incubated aerobically at $370 \mathrm{c}$ for a period of 24-48 hrs. The colonies on SDA were subjected to Germ tube test, Chlamydospore formation on corn meal agar and sugar assimilation tests for identification of species (Paulitsch et al., 2006). The color of the colonies produced on Hichrome agar was .interpreted and species identified as per manufacturers chart.

\section{Results and Discussion}

During the study period a total of 150 patients who fulfilled the inclusion criteria were included in the study. A total number of126 Candida sp were isolated from the 150 cases. Candida albicans was the commonest isolate forming 51/126(40.48\%). Theoverall prevalence of Non-albicans Candida sp in the study was 75/126(59.52\%). The important observation in the study was a striking increase of nonalbicans Candida sp with $59.52 \%$. Out of the total Candida sp, C.albicans was the commonest with 51(40.48\%) followed in order by tropicalis $24(19.04 \%)$. The other species isolated were C.glabrata 14(11.11\%), C.dubliensis 13(10.3\%), C.krusei 9(7.14\%), C.guillermondii 7(5.55\%) and C.kefyr 8(6.34\%). Among the Non-albicans Candida sp, C.tropicalis was the major species isolated $(24 / 75,32 \%)$ followed by C.glabrata $(14 / 75,18.66 \%)$ and C.dubliensis 13/75, 17.33\%).

Table demonstrates Color of the Candida species produced on Hi-chrome Candida differential chromeagar. C.albicans produced bluish green colonies,C.tropicalis metallic blue, C.glabrata pink to lilac.C.dubliensis dark green, C.krusei pink, C.guillermondii and both purplish colored colonies.

Table.1 No of candida isolated from total samples.

\begin{tabular}{|c|c|}
\hline Total no.of samples & No. of Candida isolated samples \\
\hline 150 & 126 \\
\hline
\end{tabular}

Table.2 Distribution of candida species

\begin{tabular}{|l|l|}
\hline C.albicans & $\mathbf{5 1}$ \\
\hline Non albicans sps & $\mathbf{7 5}$ \\
\hline
\end{tabular}

Table.3 Disribution of non albicans species

\begin{tabular}{|l|l|l|}
\hline Non albicans sps & Number & \% \\
\hline C.tropicalis & $\mathbf{2 4}$ & $\mathbf{1 9 . 0 4 \%}$ \\
\hline C. glabrata & $\mathbf{1 4}$ & $11.11 \%$ \\
\hline C.dubliensis & $\mathbf{1 3}$ & $10.31 \%$ \\
\hline C. krusei & $\mathbf{0 9}$ & $7.14 \%$ \\
\hline C.guillermondii & $\mathbf{0 7}$ & $5.55 \%$ \\
\hline C.kefyr & $\mathbf{0 8}$ & $6.34 \%$. \\
\hline
\end{tabular}


Table.4 Different Colours of candida species on Hichrome agar

\begin{tabular}{|l|l|}
\hline C.albicans & BLUISH GREEN \\
\hline C.tropicalis & METALLIC BLUE \\
\hline C. glabrata & PINK TO LILAC \\
\hline C.dubliensis & DARK GREEN \\
\hline C.krusei & PINK \\
\hline C.guillermondii & PURPLISH \\
\hline C. kefyr & PURPLISH \\
\hline
\end{tabular}

C.albicans was the predominant species causing VVC in our study which concurs with many studies in and abroad (Paulitsch et al., 2006; Geiger et al., 1995). Recent studies conducted by Deorukhhar and Saini (Deorukhkar et al., 2013) clearly states Non albicans Candida as emerging pathogens in cases of VVC. Many similar studies envisage the importance of non albicans Candida in various other genital candidial infections. Studies conducted by Paulitsch $e t$ al., (2006) documented the increased isolation of Non albicans Candida C.kefyr from recurrent and chronic VVC. Our study documented $59.52 \%$ of Non albicans candida which is strikingly high and concurs with the study of Richerter et al., who reports an overall $24 \%$ of Non albicans candida in his study and defers with the study of Spinillo et al., who reports only $17 \%$ in his study. Thus in recent years there has been a speculating increase in number of Non albicans candida infections which is clearly represented in our study. Among Non-albicans candida, C tropicalis was the commonest isolate which correlates with the study of Sachin C Deorukhkar et al., but is in contrast to Mohanty et al., (2007) where C.glabrata was the commonest isolate in his study. Studies done by many state that Geographical distribution of Candida is variable from place to place. Wide spread indiscriminate usage of many antimycotic drugs, Self medication, incomplete duration of administration, Misdiagnosis and inappropriate antimycotic agent without doing susceptibility are considered as some of the factors which lead to emergence of Non albicans species as major pathogens with replacement of C.albicans as a dominant pathogen.

In conclusion, in this study C.albicans still remains as most common pathogen from VVC. But there is significant increase in the prevalence of non albicans species indicates the future threat with Non albicans species.

\section{References}

Achkar, J.M., B.C. Fries. 2010. Candida infections of the genitourinary tract, Clinical Microbiology Reviews, vol. 23, no. 2, pp. 253-273, View at Publisher, View at Google Scholar, View at Scopus.

Deorukhkar, S.C. and Saini, S. Evaluation of phospholipase activity in biofilm forming Candida species isolated from intensive care unit patients. British Microbiol. Res. J., 3(3): 440-447.

Foxman, B., R. Barlow, H. D'Arcy, B. Gillespie, and J.D. Sobel. 2000. "Candida vaginitis: self-reported incidence and associated costs," Sexually Transmitted Dis., vol. 27, no. 4, pp. 230-235.

Geiger, A.M., Foxman, B., Sobel, J.D. 1995. Chronic vulvovaginal candidiasis: characteristics of women with Candida albicans, $\mathrm{C}$ glabrata, and no candida. Genitourin Med., 71: 304-7. 
Hurley, R. 1981. Recurrent candida infection. Clin. Obstet. Gynecol., 8: 209- 213.

Kent, H.L. 1991. Epidemiology of vaginitis. Am. J. Obstet. Gynecol., 165: 1168 1176.

Mohanty, S., Xess, I., Hasan, F., Kapil, A., Mittal, S., Tolosa, J.E. 2007. Prevalence and susceptibility to fluconazole of Candida species causing Vulvovaginitis. Indian J. Med. Res., 21: 216-219.

Paulitsch, A., Weger, W., GinterHanselmayer,G., Marth, E., and Buzina, W.A. 2006. 5-year (20002004) epidemiological survey of Candida and non- Candida yeast species causing vulvovaginal candidiasis in Graz, Austria. Mycoses, 49: 471-475.

Sachin, C., Deorukhkar and Santosh Saini. 2013. Vulvovaginal Candidiasis due to non albicans Candida:its species distribution and anti fungal susceptibility profile. Int. J. Curr. Microbiol. App. Sci., Volume 2Number 12, pp. 323-328.

Sobel, J.D. 1985. Epidemiology and pathogenesis of recurrent vulvovaginal candidiasis. Am. J. Obstet. Gynecol., 152: 925-935.

Sobel, J.D. 1992. Vulvovaginitis. Dermatol. Clin., 10: 339-359.

\section{How to cite this article:}

Ponugoti Muni Lakshmi. 2016. Isolation and Speciation of Candida from Vaginitis Cases attending Gynaecology OPD in a Tertiary Care Hospital A.P. India. Int.J.Curr.Microbiol.App.Sci. 5(10): 229-232. doi: http://dx.doi.org/10.20546/ijcmas.2016.510.023 